\title{
Alterations of coagulation in metformin intoxication
}

\author{
Baris Akinci ${ }^{1}$, Serkan Yener ${ }^{1}$, Goksel Bengi $^{2}$, Sena Yesil ${ }^{1}$ \\ ${ }^{1}$ Division of Endocrinology and Metabolism, ${ }^{2}$ Department of Internal Medicine, Dokuz Eylul University Medical School, \\ Izmir, Turkey
}

\begin{abstract}
It is widely known that metformin reduces the levels of circulating pro-coagulant factors and improve fibrinolytic activity in type 2 diabetes when used in therapeutic doses. Potential alterations of coagulation have not been reported in patients with metformin intoxication. We evaluated certain components of the coagulation system in a patient with metformin intoxication upon admission and after recovery. Our results indicate that both the levels of coagulation proteins synthesized by the liver and the anti-coagulant activity decrease temporarily in metformin intoxication. Nevertheless, no change in the coagulation factors secreted by the endothelium were observed.
\end{abstract}

Key words: Anticoagulants, Coagulation, Diabetes mellitus, Metformin overdose

\section{INTRODUCTION}

Metformin is a biguanide that exerts its antihyperglycemic action primarily by inhibiting hepatic gluconeogenesis and by increasing the action of insulin in certain target organs, namely muscle and fat. ${ }^{1}$ Its clinical efficacy in reducing hyperglycemia in diabetics is well established. However, while metformin decreases blood glucose levels in diabetic patients, such an effect is not observed in non-diabetic subjects. Furthermore, metformin administration is associated with weight loss, improved lipid profile, and a small reduction in blood pressure. ${ }^{2}$

Address for correspondence:

Baris Akinci, Division of Endocrinology of Metabolism, Department of Internal Medicine, Dokuz Eylul University

Medical School, Inciralti, Izmir, Turkey 35340,

Tel.: +90 232 4123744; Fax: +90 2322792267 ,

e-mail: baris.akinci@deu.edu.tr

Received 13-03-08, Revised 20-07-08, Accepted 10-09-08
Metformin has an absolute oral bioavailability of 50-60\% and gastrointestinal absorption is apparently complete within 6 hours. Metformin is not metabolized in the body and $90 \%$ of absorbed metformin is eliminated unchanged in the urine. Plasma protein binding is negligible denoting that the drug is dialyzable. ${ }^{1,3}$ The most common side effect of metformin is gastrointestinal discomfort which is reversible and can be avoided by simple interventions. ${ }^{1}$ Lactic acidosis, although rare, is a life-threatening side effect of the drug. ${ }^{4}$ Toxicity of metformin in overdose has been less clearly defined. Nevertheless lactic acidosis is also a major metabolic complication in the event of metformin intoxication. ${ }^{5}$ Management of metabolic acidosis is supportive and includes gastrointestinal decontamination, bicarbonate infusion, and hemodialysis. In cases of massive ingestion, the latter method is efficacious in removal of the drug. ${ }^{3}$

In addition to its metabolic features, metformin 
treatment is associated with reduction in coagulation proteins. ${ }^{6}$ Metformin improves impaired fibrinolytic activity in type 2 diabetes. ${ }^{7,8}$ It moreover improves fibrinolytic activity in non-diabetic subjects. ${ }^{9}$ However, alterations in coagulation have not been evaluated in metformin intoxication. We herein present alterations in certain coagulation parameters in a patient with metformin intoxication.

\section{PATIENT DESCRIPTION}

A 20-year old woman was admitted to the emergency room 48 hours after taking a toxic cumulative dose of 76.5 grams of metformin, after an argument with her husband, in order to commit suicide. She had been previously prescribed metformin $(850 \mathrm{mg} /$ day $)$ in a primary medical care center because of her obesity and impaired glucose tolerance. She had no previously diagnosed psychiatric disorder, nor was there any history of precedent or current alcohol consumption and/or over-the-counter (OTC)/herbal product use. She had had no surgery in the past.

Upon admission, the patient was suffering from nausea, vomiting, and epigastric pain. She was conscious and alert, with blood pressure $140 / 80 \mathrm{~mm} \mathrm{Hg}$, pulse rate 80 beats per minute, respiratory rate 28 breaths per minute, and body temperature $36^{\circ} \mathrm{C}$. Her weight was $77 \mathrm{~kg}$ with a BMI of $31 \mathrm{~kg} / \mathrm{m}^{2}$. She had a Glasgow Coma Scale score of 12/15. Initial investigations revealed blood urea nitrogen (BUN): 6.43 mmol/L (normal: 2.14-7.14), creatinine: $194.48 \mathrm{mmol} /$ L (normal: 70-125), sodium: $134 \mathrm{mmol} / \mathrm{L}$ (normal: 136-146), potassium: $6.0 \mathrm{mmol} / \mathrm{L}$ (normal: $3.5-5.5$ ), chloride: $100 \mathrm{mmol} / \mathrm{L}$ (normal: $98-110)$ and plasma glucose of $3.99 \mathrm{mmol} / \mathrm{L}$ (normal: 3.88-5.55). Her creatinine clearance was calculated to be $49.58 \mathrm{ml} / \mathrm{min}$ according to the Cockcroft and Gault equation $(\mathrm{CrCl}$ $=(140-$ age $) \times$ weight $/($ serum creatinine $\mathrm{x} 72) \times 0.85$ for females). Arterial blood gas showed acidosis ( $\mathrm{pH}$ : 7.33, $\mathrm{pCO}_{2}: 24.8 \mathrm{mmHg}, \mathrm{pO}_{2}: 114.8 \mathrm{mmHg}, \mathrm{HCO}_{3}$ : $13.4 \mathrm{mmol} / \mathrm{L}$, base deficit $23 \mathrm{mmol} / \mathrm{L}$, anion gap 20.6). Her serum total protein was $61 \mathrm{~g} / \mathrm{L}$ (normal: 66-87), albumin was $32 \mathrm{~g} / \mathrm{L}$ (normal: $35-52$ ). Prothrombin time and activated partial thromboplastin time were 12.7 (normal: 10.5-13.5) and 31.1 (normal: 25-35) seconds, respectively. She had leukocytosis with a left shift. Her urinary $\mathrm{pH}$ was 7 and urine specific gravity was
Table 1. Laboratory features of the patient upon admission and on discharge.

\begin{tabular}{|c|c|c|c|}
\hline & $\begin{array}{c}\text { Upon } \\
\text { admission }\end{array}$ & $\begin{array}{c}\text { On } \\
\text { discharge }\end{array}$ & $\begin{array}{c}\text { Normal } \\
\text { range }\end{array}$ \\
\hline $\mathrm{BUN}(\mathrm{mmol} / \mathrm{L})$ & 6.43 & 6.78 & $2.14-7.14$ \\
\hline Creatinine $(\mu \mathrm{mol} / \mathrm{L})$ & 194.48 & 96.36 & $70-125$ \\
\hline Sodium $(\mathrm{mmol} / \mathrm{L})$ & 134 & 138 & $136-146$ \\
\hline Potassium $(\mathrm{mmol} / \mathrm{L})$ & 6.0 & 4.4 & $3.5-5.5$ \\
\hline Chloride (mmol/L) & 100 & 99 & $98-110$ \\
\hline Glucose $(\mathrm{mmol} / \mathrm{L})$ & 3.99 & 4.94 & $3.88-5.55$ \\
\hline $\operatorname{ALT}(\mathrm{U} / \mathrm{L})$ & 15 & 14 & $1-32$ \\
\hline $\operatorname{AST}(\mathrm{U} / \mathrm{L})$ & 16 & 18 & $1-31$ \\
\hline $\operatorname{ALP}(\mathrm{U} / \mathrm{L})$ & 195 & & $34-240$ \\
\hline GGT (U/L) & 11 & & $5-36$ \\
\hline Total bilirubin $(\mu \mathrm{mol} / \mathrm{L})$ & 10.26 & & $1.71-20.52$ \\
\hline Direct bilirubin $(\mu \mathrm{mol} / \mathrm{L})$ & 1.71 & & $0.17-5.13$ \\
\hline Total protein $(\mathrm{g} / \mathrm{L})$ & 61 & & $66-87$ \\
\hline $\operatorname{Albumin}(\mathrm{g} / \mathrm{L})$ & 32 & & $35-52$ \\
\hline Amylase (U/L) & 62 & & $28-100$ \\
\hline $\mathrm{Ph}$ & 7.33 & 7.45 & $7.35-7.45$ \\
\hline $\mathrm{pCO}_{2}(\mathrm{mmHg})$ & 24.8 & 39.8 & $35-45$ \\
\hline $\mathrm{pO}_{2}(\mathrm{mmHg})$ & 114.8 & 95.4 & $83-108$ \\
\hline $\mathrm{HCO}_{3}(\mathrm{mmol} / \mathrm{L})$ & 13.4 & 28.2 & $21-28$ \\
\hline PT (seconds) & 12.7 & & \\
\hline APTT (seconds) & 31.1 & & \\
\hline $\mathrm{Hb}(\mathrm{g} / \mathrm{dl})$ & 12.1 & 12.0 & $12.0-16.0$ \\
\hline $\operatorname{Htc}(\%)$ & 35.1 & 34.9 & $36-46$ \\
\hline WBC (uL) & 10.2 & 7.0 & $4-10$ \\
\hline PNL (uL) & 7.5 & 4.4 & $2.1-6.1$ \\
\hline PLT (uL) & 302 & 270 & $156-373$ \\
\hline
\end{tabular}

ALT: Alanine aminotransferase, ALP: Alkaline phosphatase, AST: Aspartate aminotransferase, APTT: Activated partial thromboplastin time, BUN: Blood urea nitrogen, GGT: Gammaglutamyltransferase, $\mathrm{Hb}$ : Hemoglobin, $\mathrm{HCO}_{3}$ : Bicarbonate, $\mathrm{Htc}$ : Hematocrite, $\mathrm{pCO}_{2}$ : Partial pressure of carbon dioxide, PLT: Platelet count, PNL: Polymorph nuclear leukocytes count, $\mathrm{pO}_{2}$ : Partial pressure of oxygen, PT: Prothrombin time, WBC: White blood cell count.

1010. There was no proteinuria. Urine sediment was normal. Laboratory assessment is shown in Table 1. The patient was treated with oral activated charcoal and intravenous sodium bicarbonate. Hemodialysis was performed to remove metformin and to treat metabolic acidosis. The patient's condition stabilized after hemodialysis. Arterial blood $\mathrm{pH}$ rose steadily, while renal function recovered gradually. The patient was discharged in good health on the $9^{\text {th }}$ day. The 
Table 2. Coagulation parameters upon admission and on discharge.

\begin{tabular}{lccc}
\hline & $\begin{array}{c}\text { Upon } \\
\text { admission }\end{array}$ & $\begin{array}{c}\text { On } \\
\text { discharge }\end{array}$ & $\begin{array}{c}\text { Normal } \\
\text { range }\end{array}$ \\
\hline vWF $(\%)$ & 199.95 & 199.05 & $50-160$ \\
Factor II (\%) & 85.39 & 146.44 & $70-150$ \\
Factor V (\%) & 77.56 & 133.06 & $70-150$ \\
Factor VII (\%) & 56.25 & 192.34 & $60-150$ \\
Factor VIII (\%) & 142.93 & 129.6 & $70-150$ \\
Factor IX (\%) & 113.79 & 147.82 & $70-150$ \\
Factor X (\%) & 87.37 & 118.31 & $70-150$ \\
Anti-thrombin III (\%) & 99.13 & 102.38 & $75-125$ \\
Protein C activity (\%) & 70.35 & 114.02 & $60-130$ \\
Protein S activity (\%) & 36.57 & 76.72 & $60-130$ \\
\hline
\end{tabular}

vWF: von Willebrand factor

parameters of coagulation and the fibrinolytic system are demonstrated in Table 2.

\section{DISCUSSION}

In this communication we report, for the first time in the literature, a study of coagulation system proteins and natural anticoagulants in a patient with metformin intoxication. Our results demonstrate that the levels of coagulation proteins synthesized by the liver were reduced, while the levels of coagulation factors secreted by the endothelium were not affected. Depression in total protein $\mathrm{C}$ and protein $\mathrm{S}$ activities were also observed. While metformin overdose was associated with decreased levels of coagulation proteins and natural anticoagulants, synthesized by the liver, only factor VII level and total protein S activity were lower than normal.

It has been demonstrated that therapeutic doses of metformin lower circulating levels of some coagulation factors. ${ }^{6}$ Metformin treatment in type 2 diabetes reduces elevated levels of factor VII, ${ }^{10}$ and has direct effects on fibrin structure and function. ${ }^{6}$ Biguanides have been found to influence thrombin activity and fibrin polymerization, which consequently lead to decreased factor XIII activity and altered fibrin structure. ${ }^{11}$ Metformin in therapeutic doses improves endothelial function in diabetics. ${ }^{7}$ It has also been shown that metformin ameliorates endothelial function in non-diabetic subjects with insulin resistance. ${ }^{12}$
Furthermore, plasma levels of PAI-1 and vWF, which are secreted mainly by the impaired endothelium, have been shown to decrease with metformin therapy in non-diabetic subjects. ${ }^{8}$ Although metformin lowers coagulation protein levels, there is no case in the literature demonstrating hemorrhage due to metformin. Burrull-Madero et $\mathrm{al}^{13}$ reported intestinal hemorrhage caused by a Meckel's diverticulum in a patient taking metformin. However, since no investigation regarding the coagulation system was carried out in that particular case, there is no evidence to indicate that this hemorrhage was caused by metformin.

Liver dysfunction can cause both quantitative and qualitative abnormalities in clotting factors. The liver synthesizes major components of the coagulation system, including plasminogen, coagulation factors II, V, VII, IX and X, and the modulating factors protein $\mathrm{C}$, protein $\mathrm{S}$, and antithrombin III. ${ }^{14}$ In our patient, there was a clear reduction in coagulation factors synthesized by the liver, which were improved after recovery from metformin overdose. There was no alteration in the levels of vWF, which is a component of coagulation secreted by the endothelium. The levels of factor VIII, which is produced by the reticuloendothelial system (RES) and whose main source is the liver, ${ }^{15}$ were not altered. However, Stern et $\mathrm{a}^{16}$ demonstrated that endothelial cells can actively participate in procoagulant reactions involving factor VIII as well. Factor VIII synthesis was also observed in cultured human endothelial cells. ${ }^{17,18}$ The rate of factor VIII synthesis by endothelial cells in vitro corresponds to about $20 \%$ of the human factor VIII produced in vivo. ${ }^{19} \mathrm{We}$ observed higher levels of some coagulation factors after recovery from metformin intoxication. Our patient had increased vWF levels upon admission and on discharge. This might be associated with the prothrombotic condition related to her underlying disorders, namely her obesity and impaired glucose tolerance..$^{20}$

Prothrombin and factors VII, IX, and X are vitamin $\mathrm{K}$ dependent, as are the natural anticoagulants protein $\mathrm{C}$ and protein $\mathrm{S}$. Vitamin $\mathrm{K}$ dependent factors undergo post translational gamma-carboxylation, which can be impaired by vitamin K deficiency or by lack of blood clotting enzymes in liver disease. Factor VII is an important early marker of liver dysfunction, with a short half life. ${ }^{14}$ In our patient, factor VII levels 
were clearly reduced during metformin intoxication. Hepatotoxicity due to metformin, though rare, is reported in a small number of cases. ${ }^{21,22}$ The incidence of acute liver failure is reported to be $0.12 \%$ in metformin treated patients. ${ }^{23}$ Acute cholestatic jaundice after metformin treatment has also been reported in the literature. ${ }^{24}$ As we were not able to demonstrate elevated parenchymal liver enzymes in our patient, hepatocyte injury is not substantiated. However, decreased levels of coagulation system components synthesized by the liver might reflect a temporary defect in hepatic function.

Laboratory assessments upon admission showed a number of other alterations in our patient besides coagulation changes, metabolic acidosis being the main one. Metformin may lead to lactic acidosis even in therapeutic doses, mostly in patients with impaired renal functions. ${ }^{4}$ Lactic acidosis related to metformin overdose has been reported in several cases. ${ }^{4,25,26}$ Type-A lactic acidosis is associated with tissue hypoxia as ensues in sepsis. Lactic acidosis seen during metformin overdose, or type- $\mathrm{B}$, occurs in the absence of hypoxia. ${ }^{25}$ The pathogenesis of metformin induced lactic acidosis has not been fully clarified. It is considered that toxic doses of metformin affect electron transport at the mitochondrion membrane and inhibit oxidative metabolism. Eventually, aerobic metabolism switches to anaerobic metabolism and accumulation of lactic acid occurs. ${ }^{27}$ Although lactate accumulation plays a central role in the development of acidosis, no correlation has been observed between mortality and lactate or metformin levels. ${ }^{28,29}$ Hemodialysis is a good choice of treatment for metabolic acidosis related to metformin. Sodium bicarbonate alone usually fails to correct the acidosis; however, it may be used in selected patients with mild acidosis. ${ }^{3,29,30}$ Another basic laboratory finding of the patient was hyperkalemia. It resolved after the metabolic acidosis had been treated. She also had mild hyponatremia, which probably reflects reduced water clearance due to reduced glomerular filtration rate (GFR). Extrarenal losses and inappropriate secretion of antidiuretic hormone (ADH) are other common causes of hyponatremia. ${ }^{31}$ Leucocytosis with left shift might result from acidosis induced overproduction of catecholamines. ${ }^{32}$ Blood gas analysis of the patient showed reduced $\mathrm{pCO}_{2}$, which was associated with compensatory hyperventilation.

In conclusion, we showed that metformin intoxication is associated with a temporary decrease in proteins of the coagulation system synthesized by the liver with no effect on the coagulation factors produced by the endothelium.

\section{REFERENCES}

1. Bailey CJ, Turner RC, 1996 Metformin. N Engl J Med 334: 574-579.

2. Campbell IW, Howlett HC, 1995 Worldwide experience of metformin as an effective glucose-lowering agent: a meta-analysis. Diabetes Metab Rev 11: Suppl 1: 5762.

3. Teale KF, Devine A, Stewart H, Harper NJ, 1998 The management of metformin overdose. Anaesthesia 53: 698-701.

4. Chang CT, Chen YC, Fang JT, Huang CC, 2002 Metformin-associated lactic acidosis: case reports and literature review. J Nephrol 15: 398-402.

5. Brady WJ, Carter CT, 1997 Metformin overdose. Am J Emerg Med 15: 107-108.

6. Grant PJ, 2003 Beneficial effects of metformin on haemostasis and vascular function in man. Diabetes Metab 29: 6S44-52.

7. Hamilton SJ, Chew GT, Watts GF, 2007 Therapeutic regulation of endothelial dysfunction in type 2 diabetes mellitus. Diab Vasc Dis Res 4: 89-102.

8. Charles MA, Morange P, Eschwege E, et al, 1998 Effect of weight change and metformin on fibrinolysis and the von Willebrand factor in obese nondiabetic subjects: the BIGPRO1 Study. Biguanides and the Prevention of the Risk of Obesity. Diabetes Care 21: 1967-1972.

9. Diamanti-Kandarakis E, 2006 Insulin resistance in PCOS. Endocrine 30: 13-17.

10. Grant PJ, 1998 Metformin reduces circulating factor VII concentrations in patients with type 2 diabetes mellitus. Thromb Haemost 80: 209-210.

11. Standeven KF, Ariens RA, Whitaker P, et al, 2002 The effect of dimethylbiguanide on thrombin activity, FXIII activation, fibrin polymerization, and fibrin clot formation. Diabetes 51: 189-197.

12. Diamanti-Kandarakis E, Alexandraki K, Protogerou A, et al, 2005 Metformin administration improves endothelial function in women with polycystic ovary syndrome. Eur J Endocrinol 152: 749-756.

13. Burrull-Madero MA, Del-Villar-Ruiz A, Grau-Cerrato S, Andreu-Garcia M, Goday-Arno A, 2001 Digestive hemorrhage caused by a Meckel's diverticulum in a metformin-treated patient: is there any connection? Pharm World Sci 23: 120-121.

14. Sallah S, Bobzien W, 1999 Bleeding problems in patients with liver disease. Ways to manage the many hepatic effects 
on coagulation. Postgrad Med 106: 187-190, 193-185.

15. Webster WP, Zukoski CF, Hutchin P, et al, 1971 Plasma factor VIII synthesis and control as revealed by canine organ transplantation. Am J Physiol 220: 1147-1154.

16. Stern D, Nawroth P, Handley D, Kisiel W, 1985 An endothelial cell-dependent pathway of coagulation. Proc Natl Acad Sci U S A 82: 2523-2527.

17. Jaffe EA, 1975 Synthesis of factor VIII antigen by cultured human endothelial cells. Ann N Y Acad Sci 240: 62-69.

18. Jaffe EA, Hoyer LW, Nachman RL, 1973 Synthesis of antihemophilic factor antigen by cultured human endothelial cells. J Clin Invest 52: 2757-2764.

19. Jacquemin M, Neyrinck A, Hermanns MI, et al, 2006 FVIII production by human lung microvascular endothelial cells. Blood 108: 515-517.

20. Meigs JB, Mittleman MA, Nathan DM, et al, 2000 Hyperinsulinemia, hyperglycemia, and impaired hemostasis: the Framingham Offspring Study. Jama 283: 221-228.

21. Kutoh E, 2005 Possible metformin-induced hepatotoxicity. Am J Geriatr Pharmacother 3: 270-273.

22. Nammour FE, Fayad NF, Peikin SR, 2003 Metformininduced cholestatic hepatitis. Endocr Pract 9: 307-309.

23. Chan KA, Truman A, Gurwitz JH, et al, 2003 A cohort study of the incidence of serious acute liver injury in diabetic patients treated with hypoglycemic agents. Arch Intern Med 163: 728-734.

24. Desilets DJ, Shorr AF, Moran KA, Holtzmuller KC, 2001 Cholestatic jaundice associated with the use of metformin. Am J Gastroenterol 96: 2257-2258.
25. Galea M, Jelacin N, Bramham K, White I, 2007 Severe lactic acidosis and rhabdomyolysis following metformin and ramipril overdose. Br J Anaesth 98: 213-215.

26. Harvey B, Hickman C, Hinson G, Ralph T, Mayer A, 2005 Severe lactic acidosis complicating metformin overdose successfully treated with high-volume venovenous hemofiltration and aggressive alkalinization. Pediatr Crit Care Med 6: 598-601.

27. Bruijstens LA, van Luin M, Buscher-Jungerhans PM, Bosch FH, 2008 Reality of severe metformin-induced lactic acidosis in the absence of chronic renal impairment. Neth J Med 66: 185-190.

28. Lalau JD, Mourlhon C, Bergeret A, Lacroix C, 1998 Consequences of metformin intoxication. Diabetes Care 21: 2036-2037.

29. Panzer U, Kluge S, Kreymann G, Wolf G, 2004 Combination of intermittent haemodialysis and high-volume continuous haemofiltration for the treatment of severe metformin-induced lactic acidosis. Nephrol Dial Transplant 19: 2157-2158.

30. Heaney D, Majid A, Junor B, 1997 Bicarbonate haemodialysis as a treatment of metformin overdose. Nephrol Dial Transplant 12: 1046-1047.

31. Gross P, 2008 Treatment of hyponatremia. Intern Med 47: 885-891.

32. Benschop RJ, Rodriguez-Feuerhahn M, Schedlowski M, 1996 Catecholamine-induced leukocytosis: early observations, current research, and future directions. Brain Behav Immun 10: 77-91. 